\title{
"Ser macho neste país é coisa de macho": a culturalização da masculinidade e sua relação assimétrica com a igualdade
}

Marco Julián Martínez Moreno

\section{(2) OpenEdition \\ Journals}

Edição electrónica

URL: http://journals.openedition.org/aa/1795

DOI: $10.4000 /$ aa. 1795

ISSN: 2357-738X

Editora

Programa de Pós-Graduação em Antropologia Social (UnB)

Edição impressa

Data de publição: 1 dezembro 2016

Paginação: 33-56

ISSN: 0102-4302

\section{Refêrencia eletrónica}

Marco Julián Martínez Moreno, «"Ser macho neste país é coisa de macho": a culturalização da masculinidade e sua relação assimétrica com a igualdade», Anuário Antropológico [Online], v.41 n.2 2016, posto online no dia 15 junho 2018, consultado o 27 abril 2021. URL: http:// journals.openedition.org/aa/1795 ; DOI: https://doi.org/10.4000/aa.1795

\section{(c) $)(9)$}

Anuário Antropológico is licensed under a Creative Commons Atribuição-Uso Não-Comercial-Proibição de realização de Obras Derivadas 4.0 International. 


\title{
"Ser macho neste país é coisa de macho": a culturalizaçáo da masculinidade e sua relação assimétrica com a igualdade
}

\author{
Marco Julián Martínez Moreno
}

UnB

Neste artigo, proponho complementar a análise individualista do campo das masculinidades com as noçóes de pessoa e reciprocidade, para compreender melhor relaçóes tidas por violentas e sujeitos que, nesse campo, são constituídos em oposição moral à noçãa de cidadão. Com isto, proponho a revisão de supostos éticos do pesquisador quando tenta classificar e analisar identidades, práticas e relaçóes a partir de uma perspectiva de gênero que se encontra em estreita relação com as moralidades intrínsecas ao uso da categoria de cultura. Por último, busco revisar como os "outros" apropriam-se de categorias analíticas, como cultura e gênero, de modo tal que elas adquirem vida e dinâmica própria no contexto de implantação de leis e políticas de reconhecimento da dignidade humana da mulher.

Em primeiro lugar, caracterizo o campo das masculinidades, particularmente a partir da sua relação analítica com a violência, e mostro a relação desse campo com o contexto político colombiano. Em seguida, justifico a pertinência de valorizar a pessoa e as relaçóes de reciprocidade na análise de gênero. Feito isto, faço uma reinterpretação de dados de campo de um projeto de intervenção social em masculinidade do qual participei como pesquisador e gestor de política pública. Por último, antes das consideraçôes finais, apresento o Movimento Machista Casanareño como um fenômeno colateral da implantação de políticas de gênero.

\section{O campo das masculinidades e a abordagem da violência}

Nos últimos trinta anos, a abordagem das masculinidades na América Latina tem se caraterizado como um campo interdisciplinar que conjuga estudos de gênero e sexualidade com intervenção psicossocial e jurídica. Tanto analistas como gestores de política pública buscam compreender relaçóes de poder e propor a transformação das identidades masculinas nas suas relaçóes sociais cotidianas em razão de privilégios, violências e opressóes que os homens exercem sobre as mulheres. Este campo integra trabalhos heterogêneos que respondem a 
variadas orientaçôes e interesses em relação ao desenvolvimento social, à inserção das mulheres no trabalho formal, ao fim da violência contra as mulheres, à apropriação do corpo dimensionado pelo gênero, à sexualidade, à saúde e aos direitos e à transformaçáo das relaçóes entre pais e filhos, promovendo a dimensão do cuidado na criação. Alguns autores na América Latina tentam contextualizar a relação entre identidades masculinas e violências históricas e estruturais, produto da colonização europeia, do desenvolvimento do capital, da dominação de oligarquias e dos regimes militares. Outros, na fronteira entre academia e intervenção social, tentam sair de lugares-comuns relativos à dicotomia agressor versus vítima ao mesmo tempo que vinculam as masculinidades a "complexos culturais" machistas (Viveros, 2002, 2003).

A contextualização etnográfica permitiu compreender complexas trajetórias pelas quais os homens terminam ora exercendo violência, ora participando de contextos em que ela é exercida, para mostrar como relaçóes e identidades tidas por tradicionais ou culturais legitimam desigualdades, desvantagens, vexames e vulnerabilidades para mulheres e alguns tipos de homem. Ao mesmo tempo que dá argumentos a ativistas e gestores para propor normativas de proteção, essa visibilidade sofistica procedimentos de intervenção social e atendimento psicossocial. Porém, precisamente esta categoria, "violência", aparece como um dado sociológico que conjuga explicaçôes culturalistas, que remetem ao passado; análises das relaçôes de poder, que mostram um presente problemático; e imperativos filosóficos sobre os direitos humanos, que projetam um futuro utópico e incerto. Voltarei a este ponto.

Com a emergência de leis e políticas públicas de combate à violência de gênero ou contra as mulheres, o campo retoma o par agressor versus vítima e integra categorias penais próprias do mundo jurídico - violência psicológica, sexual, de gênero, intrafamiliar, patrimonial, entre outras - com o qual tenta enquadrar relaçóes sociais em categorias contratuais. Autores na fronteira entre o ativismo, a intervenção social e a academia conjugam a análise da psicologia do indivíduo com a sociologia e a antropologia para dar conta da participação e autoria dos homens em contextos e relaçóes que desconsideram a pessoa humana da mulher, passando das relaçóes de casal ao conflito armado (Beiras, 2012; Nascimento, 2001), e configurando "ciclos da violência" que não permitem à vítima romper sua relação com o agressor. Destaco duas posiçóes intelectuais que têm dominado nesses trabalhos: uma inspirada em Gramsci e outra desenvolvendo postulados pós-estruturalistas, que se conjugam de várias maneiras para dar conta de como os homens estáo marcados pelo gênero e constroem suas relaçóes de poder e dominação com as mulheres e outros homens. 
A primeira aproximação apela à definição de "masculinidade hegemônica" para classificar formas de autoridade e exercícios de poder divergentes da concepção liberal de indivíduo, que possui direitos inalienáveis e cuja expectativa é o tratamento igualitário no âmbito público. A masculinidade hegemônica foi proposta por Raewyn Connell (2005; Connel \& Messerschmidt, 2005) para problematizar assimetrias de jovens escolarizados na Austrália e enfatiza os papéis, a mudança e o contexto onde ela é exercida. Trata-se de uma noção similar à ideia de estrutura que é estruturada e estruturante, na qual a hegemonia é entendida contextualmente e estabelece duas classes de pessoas: as que exercem poder sobre os outros e as que são oprimidas, caracterizadas como "masculinidades subordinadas". Nas palavras de Miguel Vale de Almeida (1996), a masculinidade hegemônica seria um modelo cultural ideal inalcançável pelos homens, exercendo sobre todos eles (as mulheres também) um efeito controlador, constituído por assimetrias e hierarquias que resultam em uma constante vigilância e disputa na aquisição, manutenção e definição do modelo.

A outra aproximação faz referência às obras de Michel Foucault e Judith Butler para dar conta do gênero como propriedade do indivíduo, bem como efeito das performances linguísticas e relaçóes de poder entre categorias femininas e masculinas e entre homens e mulheres, que definem suas posições no discurso e nas relaçóes sociais. Isto sobrepóe os homens que encarnam mais fielmente a norma às mulheres e a outros homens, como os homossexuais, por exemplo. Estas posiçôes dependem discursivamente da valoraçáo de certo tipo de masculinidade que, passando ao plano político do campo, é definida como hegemônica, violenta, machista ou patriarcal. Por outro lado, esta perspectiva de análise, que dialoga com outras formas de conceber o gênero — ora desde as políticas da diferença, ora desde a filosofia do devir - , permite apreciar matizes, misturas e trânsitos entre categorias. Os analistas outorgam dignidade analítica a indivíduos e coletivos que desafiam ou contestam as categorias fixas de gênero, cuja agência os faz se colocarem como sujeitos políticos que questionam ordens de poder excludentes relativas ao sujeito transcendente humanista: o cogito cartesiano. Isto mostra o engajamento do analista em relação ao projeto filosófico que faz sentido para ele.

\section{Masculinidade, cultura e violência na Colômbia}

Dada a especificidade do contexto político colombiano, caracterizado por conflito armado, narcotráfico e outras modalidades de violências tradicionais, interpessoais ou de gênero, justificadas sempre pela objetivação acadêmica da cultura de la violencia, estudar e explicar aos homens também tem como referente 
a questão cultural. Vincula-se agressividade, identidade e cultura para explicar a impossibilidade da estabilidade democrática da "paz" como valor político na sociedade colombiana. Neste esquema, mostra-se como certos exercícios de poder são caracterizados como "violência", e a atitude do homem, como "machismo".

Cultura de la violencia é uma maneira de entender o período da historiografia colombiana de La Violencia, que desde 1948 até 1960 se caracterizou pelo enfrentamento "fratricida" entre liberais e conservadores nas pequenas cidades e áreas rurais das regiōes andina e da Orinoquia, pela emergência das primeiras guerrilhas de esquerda e pela restauração da ordem cívica com o governo militar de Gustavo Rojas Pinilla. Para Germán Guzmán (1968), autor do clássico estudo La violencia en Colombia, parte descriptiva, a cultura da violência é resultado do deslocamento de populaçôes rurais às grandes cidades, por causa dos enfrentamentos armados, gerando um trauma entre os jovens que passaram de uma cultura integrada de maneira harmônica com o ambiente rural a um ambiente urbano pobre e marginal nas grandes cidades. Esta ruptura transformou jovens em delinquentes que integraram estruturas mafiosas, promotoras da guerra, do tráfico e da violência em todos os âmbitos da vida social. A violência aparece como alfa e ômega em uma lógica de causa e efeito que quebrou um passado harmônico, dando como resultado um presente problemático.

Desde os últimos anos da década de 1970, esta forma de explicar o conflito tem sido frequente no discurso político colombiano para justificar açôes estatais de uso da força armada contra guerrilhas, populaçóes rurais e setores marginais das cidades, bem como desenhar políticas e leis para garantir o direito à paz. A normatividade emergente buscou incidir tanto no conflito armado quanto na família, considerando-a núcleo da sociedade. Também entre as décadas de 1970 e 1980 entraram em cena as análises de gênero e feministas na academia e no debate público, introduzindo o conceito de "cultura patriarcal" e reivindicaçóes do direito à não violência. $\mathrm{O}$ propósito era demonstrar como as mulheres eram maltratadas e morriam não só por causa da guerra, mas pela manutenção de certa ordem de gênero nas relaçóes conjugais e familiares.

A participaçáo política das mulheres no Estado permitiu a criação de leis e políticas que almejavam a igualdade entre homens e mulheres e a proteção contra a violência, incorporando as recomendaçóes internacionais das convençóes para a Eliminação de todas as Formas de Discriminação contra a Mulher (CEDAW, na sigla em inglês) e de Belém do Pará sobre violência contra a mulher, entre outras relativas aos direitos humanos das mulheres. Esta filosofia ficou oficializada com a Constituição Política de 1991, que instaurou o Estado social de Direito. A partir desse momento, o propósito político permitiu a existência de uma cultura 
democrática, fazendo da família um espaço de formação de cidadãos. Além disso, as associações entre cultura, violência e patriarcado possibilitaram a objetivação dos homens e do masculino como alvo de estudos. Possibilitaram, ainda, políticas de transformaçáo de uma masculinidade hegemônica, machista, guerreira ou patriarcal em uma "nova", que valorizasse a igualdade, a democracia e a paz como componentes da cidadania.

Para autores como Freddy Gómez e Carlos Iván García (2006), influentes na concepçáo de esquemas de intervenção nas masculinidades na Colômbia, os homens no país compartilham um "ethos guerreiro" (que lembra a formulação de Maurice Godelier sobre os Baruya), sinônimo de "ser verdadeiro homem". A partir da leitura do trabalho de María Victoria Uribe, Matar, rematar y contramatar, acerca da sevícia no período de La Violencia em uma regiáo dos Andes colombianos, Gómez e García exemplificam historicamente o ethos mostrando o tratamento cruel e desumanizado no assassinato de opositores políticos. Posteriormente, apontam que o ethos reproduz-se até hoje na criação e na socialização masculina, modelando o corpo, reprimindo a expressão emocional, criando hierarquias de mando entre os homens e, finalmente, configurando a identidade individual.

Os homens colombianos são simultaneamente vítimas do patriarcado e perpetradores da violência - situam-se, portanto, no eixo onipotência/ impotência, que acarreta tensões e contradiçóes com o valor da "masculinidade hegemônica guerreira" do país. Isso se traduz em experiências de sofrimento e renúncias individuais para chegar a ser um homem. Os autores veem na possibilidade da contradição a abertura para uma "nova masculinidade", assumida como alternativa de recomposição nacional, possível pela reflexão individual do costume e da tradição, pela experiência presente da dor e pela consideração de se assumir como homem em relação de igualdade com as mulheres.

$\mathrm{Na}$ Colômbia, as associaçóes entre masculinidade hegemônica, machismo e patriarcado permitiram incluir uma perspectiva de gênero na análise sociológica e vincular, de maneira funcional, a escala nacional do conflito armado a outras relativas a violaçóes de direitos das mulheres na família e nas relaçóes cotidianas. Deste modo, estabelece-se um contínuo entre indivíduo e sociedade, sendo o primeiro responsável pela estabilidade do segundo, e desvelam-se tradiçóes, culturas e estruturas sociais desajustadas em relação a um projeto de sociedade igualitária e indivíduo liberal. Assim, observamos uma aproximação a discursos e práticas de uma masculinidade hegemônica englobada pela cultura e antagônica à ideia de cidadania da filosofia dos direitos humanos. 


\section{Individualismo, gênero e reciprocidade}

Ao mesmo tempo que contribui com este campo, considerando a diversidade de identidades e práticas de "homens" em relação a outros homens e mulheres, a antropologia problematiza a implantaçáo desta categoria no singular, em contextos etnográficos "não ocidentais" ou em processo de modernização. Boa parte da produção acadêmica sobre os homens e as masculinidades emergiu da crítica dos estudos de gênero e feministas ao lugar da mulher na vida social e dos desafios de mostrar os homens como marcados pelo gênero. Porém, como argumenta Matthew Gutmann (1997), a antropologia também tem se preocupado com papéis e posicionamentos diferenciais de homens e mulheres desde seu nascimento como campo disciplinar autônomo, através do exame de categorias tais como "patriarcado", por Morgan, "autoridade" e "pulsão sexual”, por Malinowski, ou "caráter", por Mead. A antropologia também implodiu categorias de gênero na análise de contextos etnográficos, mostrando como elas se relacionam com as noções de "indivíduo" e "sociedade", próprias da epistemologia moderna (Moore, 2007; Strathern, 2006), razão pela qual está ciente da apercepção sociológica que produz um olhar individualista, nas palavras de Louis Dumont.

O programa intelectual de Dumont (1970) contrastou o lugar do indivíduo no Ocidente e no sistema de castas indiano e mostrou como, para o primeiro, o indivíduo constituía um valor que se contrapunha à noção de hierarquia, contemplada no holismo indiano. $\mathrm{O}$ individualismo postula o indivíduo como sujeito moral que representa o social, possuidor dos valores da igualdade e da liberdade, que o emancipa da tirania da tradição e da coletividade. Desvelando o individualismo, Dumont "desnaturalizou" a relação entre indivíduo e sociedade como um problema sociológico, mostrando certa "cegueira" diante do social. Ele alude ao termo "apercepção sociológica" para argumentar que noçóes como pessoa e indivíduo são construtos socioculturais que imprimem uma visáo particular à análise sociológica e que fazem que os indivíduos do individualismo moderno sejam o prisma de observação de sociedades etnográficas ou históricas.

Em razão disso, Dumont apela à aquisição de consciência por parte dos pesquisadores para distinguir entre o princípio ideal do analista e o dos interlocutores no campo (Stolcke, 2001). Este alerta tem sido acolhido recentemente pelos antropólogos, do qual derivam não só consideraçóes sobre os limites das categorias na constituição do outro etnográfico como o registro das mudanças dos "modelos ocidentais" e suas apropriaçóes pelos "outros", que se posicionam diante de discursos de poder como os da cultura, do indivíduo ou da sociedade. Quando faço referência ao modelo ocidental, estou falando de uma epistemologia que informa tanto os discursos acadêmicos, incluídos os dos antropólogos, quanto 
os utilizados pelo "cidadão comum". Considero que o registro de problemáticas sociais, o olhar etnográfico, a interpretação sociológica e o agir político a partir da categoria de masculinidade são susceptíveis à crítica levantada por Dumont, mostrando o caráter etnocêntrico e sociocêntrico desta categoria.

A ênfase no indivíduo e sua performance não pode ser descartada na análise antropológica; porém, um vasto material etnográfico sustenta que as categorizaçóes de gênero estão também baseadas nos papéis, naquilo que homens e mulheres fazem, estando a performatividade relacionada à construção simbólica das categorias de gênero. Em outras palavras, a compreensão das diferenças de gênero também envolve o conceito de pessoa e os indivíduos marcados pelo gênero, dado que também se fala desde suas posiçóes nas relaçóes sociais. Aqui as noçóes de pessoa e reciprocidade são importantes para a análise, pois a partir delas podemos caracterizar lugares morais, expectativas sociais e precedências nas relaçôes sociais para compreender melhor o lugar do sujeito no discurso (Moore, 1994, 2007). Reciprocidade e pessoa são formulaçôes clássicas feitas por Marcel Mauss (2011), que, a partir do trabalho de Malinowski (1973), entre outros autores, colocou a dádiva no centro da reflexão da constituição do elo social.

As três obrigaçóes encadeadas de dar, receber e retribuir têm tido potencial heurístico para a antropologia. Elas mostram como circulam não só bens, mas palavras, valores, sentimentos e símbolos, que outorgam formas e conteúdos particulares nas relaçóes sociais. Mostram também como o que circula não é a representação da pessoa, mas a pessoa em si, salientando, por um lado, a inalienabilidade entre a pessoa e o conteúdo da relação social e, por outro, como aquilo que circula faz parte da noçáo de si dos doadores. Mesmo que as pessoas sejam interdependentes, isto não significa que não possam ser concebidas como indivíduos, que não exista uma individualidade ou que não tenham capacidade de agência ou intencionalidade. Isso também não implica que as açôes das pessoas não sejam avaliadas em termos de trajetória ou carreira individual. Não existe uma oposição ou uma precedência evolutiva entre pessoa e indivíduo. Abordar a reciprocidade permite analisar a relação entre indivíduo, posição social e papel, bem como questóes sobre agência e estrutura, hierarquia, assimetria e poder. Com isto, debate-se o suposto da contratualidade da sociedade, o princípio de interesse do indivíduo moderno e a noção de sociedade em si (Strathern, 2006). Também se mostra como aquilo que podemos chamar de cultural possui um ordenamento, uma lógica, uma forma e um conteúdo relativos à organização e circulação das dádivas.

Daqui deriva que, mesmo encontrando morfologias sociais similares em contextos diferentes, elas não necessariamente são as mesmas no seu conteúdo. 
Por essa razão, categorias como "machismo", que caracteriza relaçôes de poder na América Latina, como se ela fosse uma região cultural homogênea, dizem mais respeito à perspectiva moderna de quem as enuncia que à maneira como homens $\mathrm{e}$ mulheres configuram relaçôes de poder em contextos específicos. Destaco a tensa relação entre empirismo e construtivismo social proposta aqui para fazer uma aproximação contextualizada à constituição do elo social dos nossos interlocutores. Também recorro a essa relação para ver como tais interlocutores se posicionam perante a tentativa classificatória do analista e como as propostas corretivas ou preventivas podem apelar a uma "lógica" que faça sentido aos atores envolvidos, ${ }^{1}$ permitindo a "mudança social e cultural" através da negociação, subversão e redefinição de categorias e relaçóes sociais.

\section{Releitura de um trabalho de intervençáo em masculinidades}

Nesta seçáo, apresento uma releitura de dados de campo de 2005, quando participei como pesquisador e gestor de política pública de um programa de prevenção à violência intrafamiliar em Bogotá, Colômbia, destacando elementos da reciprocidade de narrativas que inicialmente foram interpretadas desde o ângulo da cidadania. $\mathrm{O}$ propósito do trabalho de intervenção com grupos de homens era propiciar mudanças culturais na família a partir da reflexão e crítica de práticas, referentes e imaginários socioculturais que legitimam o uso da violência na família com a finalidade de criar relações democráticas no lar. ${ }^{2}$ O grupo executor do projeto fazia parte da Universidade Nacional de Colômbia e estava conformado por antropólogos, psiquiatras, advogados, psicólogos e educadores, responsáveis por desenhar um método que partia das experiências sociais dos participantes para depois passar à reflexão crítica grupal. $\mathrm{O}$ facilitador do grupo colocava a perspectiva da política pública e da teoria de gênero resenhada nos parágrafos anteriores. Uma vez feita a reflexão, procurava-se o planejamento da vida familiar tendo como referentes éticos noçóes como cidadania e igualdade (Jimeno et al., 2007).

No debate acerca do significado de ser homem e das razóes pelas quais um homem deve ou pode se comportar de certa maneira, pretendia-se manter uma relativa autoridade do facilitador como representante do Estado e da academia. Mas o que acontecia era a emergência de uma tensão ou disputa em que o facilitador colocava um sentido da masculinidade e do poder, e os frequentadores do grupo, outros. $\mathrm{O}$ resultado era um discurso polarizado, na interação entre categorias relativas ao projeto social igualitário e categorias de parentesco, direito e gênero dos participantes. Assim, não encontramos um "discurso nativo sobre a masculinidade", com o qual reflexos ou representaçóes da masculinidade 
seriam capturados pelos facilitadores, mas categorias e sentidos na interação entre perspectivas de mundo, no encontro entre o desejo de simetria e a assimetria expressa pelos participantes no campo. Nesse encontro, alguns preconceitos foram questionados, pois, à medida que os participantes justificavam seus atos como homens, a maioria das vezes em relação a suas mães, irmãs, companheiras ou filhas (e, em menor medida, a seus pais, filhos ou outros homens), a autoridade esclarecida do facilitador desaparecia - ele tinha que justificar por que não era táo marica como parecia. Em outras palavras, a masculinidade era um discurso ativado pela retórica igualitária, uma forma de conceber e pensar os outros desde uma epistemologia moderna.

Um dos perfis populacionais com que trabalhei, que abordei com maior profundidade em outros lugares (Martínez, 2012a, 2012b, 2013, 2014 e 2016), foi o de jovens moradores de rua institucionalizados em um centro de acolhida administrado por uma ordem de religiosos católicos de longa tradição de educação a setores marginais da cidade. Esses jovens tinham que passar pelo ciclo de oficinas como parte de um currículo de ressocialização e formação para o trabalho. Eles eram consumidores de maconha, crack ou cola de sapateiro; tinham entre $11 \mathrm{e}$ 18 anos; muitos não tinham educação primária ou eram analfabetos funcionais; e moravam nos bairros próximos à instituição, caracterizados pela prefeitura de Bogotá como de "alto risco social".

Esses jovens concordavam com os atributos do que no momento foi chamado de "masculinidade hegemônica": um homem dominante, heterossexual, machista, protetor, provedor econômico, entre outros traços de gênero que circulavam no debate público e que pretendiam ser desnaturalizados nos encontros. Porém, o adjetivo "machista" era rejeitado, pois implicava ser violento com as mulheres, que deviam ser protegidas. Os atributos hegemônicos correspondiam, em parte, à valorizada figura do papá, o cucho, descrito como trabalhador e responsável pelo bem-estar da sua mulher e dos filhos. O interessante é que o cucho era uma figura moral ausente na vida deles — muitos não o conheciam —, mas colocada pelos religiosos da instituição como chefe da família e pelos agentes de políticas sociais como necessária para uma correta criação.

Em outros encontros realizados com homens adultos, muitos deles já pais, foi recorrente escutar que o trabalho os dignificava, pois lhes permitia aportar: dar ou trazer dinheiro, comida e roupas para o lar. Estes homens mencionavam seu mal-estar quando não podiam trazer dinheiro, comida ou roupas para casa, experimentando vergonha e impotência, pois aquilo os colocava em uma posição desconfortável diante da exigência das suas companheiras para a manutenção do lar. Não poder justificar estas situaçóes os levava a brigar, por se sentirem 
humilhados, mas também a aceitar que suas companheiras tinham que trabalhar. A incapacidade de aportar os deixava inseguros, porque achavam que facilmente elas se interessariam por outros homens: o medo era o de serem traídos e abandonados. Esses adultos expressavam "a mudança dos papéis" e a dificuldade de assumir uma "nova masculinidade", pois, quando a troca era rompida, ficava evidente o caráter da dádiva, resultando em reclamações e agressões mútuas que não eram concebidas, no início, desde uma perspectiva contratual como "violência intrafamiliar".

Os jovens aprendiam a ser responsáveis no instituto de acolhida. $\mathrm{Na}$ casa, muitas vezes eram desvalorizados por não terem capacidade de aportar; no entanto, eram amados como filhos pelas cuchas: a mãe, a avó ou alguma tia. Elas exerciam autoridade relacionada a sentimentos de afeto, carinho e proteção, o que gerava a obrigatoriedade entre os jovens de respeitá-las, cuidá-las, protegê-las e ser responsável com elas. A cucha era a pessoa de máxima estima, e insultá-la implicava grave ofensa à sua santidade, extensível às irmás. $\mathrm{O}$ fato de outros homens, particularmente o padrasto, as maltratarem, insultarem e, muitas vezes, estuprarem gerava ira e dor nos jovens, mas também impotência. Os jovens não podiam confrontá-los, pois às vezes elas justificavam o comportamento abusivo dos seus companheiros sentimentais, ou seriam objeto de retaliação desses homens. Para muitos dos jovens, viver esse tipo de situação em casa gerava desconfiança, desesperança e ressentimento sem, contudo, implicar a perda do amor materno e o carinho deles para com elas.

Ser um violador era uma identificação depreciável, utilizada para desqualificar um par — uma ofensa máxima, que não correspondia às virtudes do pai responsável, mas que também não correspondia ao "machista". Ser violador dizia respeito a transgredir a santidade da cucha, embora não ao desconhecimento dos direitos dela como mulher. Neste esquema, quando era insuportável a indignação e os vexames, só uma figura alheia à casa, investida de poder institucionalizado, podia exercer a coerçáo e a ameaça da puniçáo para parar os violadores. $\mathrm{O}$ agente institucional podia ser um policial, mas também o traficante ou o paramilitar que dominava o bairro. Ele tinha poder suficiente para resolver a "violência" e confrontar, ameaçar ou matar o abusador, legitimando a proteção à "vítima" e restituindo o lugar sacralizado dela.

Estes jovens mostraram uma imagem da "violência na família" dimensionada por problemas, em oposição a um ideal de família nuclear, valorizada pela política pública e ativada através da retórica dos direitos. O “diálogo na família”, mais que uma relação horizontal de indivíduos que se reconheciam na sua singularidade, era uma relação direcionada dos mais velhos para os mais jovens, em um 
intercâmbio de experiência por obediência. Esta relação também era estimulada pelo padre, pela freira e pela assistente social do instituto de acolhida. Os jovens esperavam conselhos dos mais velhos, que condensavam uma experiência de vida socialmente reconhecida através do sucesso pessoal, da manutenção dos mais velhos, da construção e ampliação da casa, da providência econômica e da intensidade do amor de máe.

A familia como valor, compartilhada em alguma medida pelos jovens e pela institucionalidade, foi a referência para medir o grau da violência intrafamiliar. Os problemas englobavam descriçôes de expectativas não cumpridas e desconhecimentos mútuos entre os integrantes da casa, lugar de moradia definido pela presença da cucha. Apesar de a família ser um referente moral e idealizado pela autoridade do pai (inexistente), a casa de fato estava governada pela cucha. Com ela, construía-se o sentido da responsabilidade, estimulado com a saída dos homens para ser trabalhadores e o retorno deles como protetores e provedores. Esses jovens aprendiam a administrar a experiência e adquirir responsabilidade no trânsito entre a casa e a rua. Experiência e responsabilidade ajudam na conformação de uma dignidade para si, da individualidade, para se colocar com autoridade diante dos outros, inclusive das instituiçóes, de modo a fazer valer seus direitos como cidadão. Mas um homem responsável com experiência estava sempre inserido em relaçóes econômicas, afetivas e de reconhecimento social que não dependiam só da sua individualidade ou concepção de si como sujeito com direitos que considera os outros como iguais.

Desde a proposta governamental de se pensar como um homem com uma nova masculinidade, a "violência" revelou relaçóes conflitivas que não estavam mediadas pela contratualidade dos direitos entre indivíduos, nem pelo fato de um patriarca possuir direitos sobre os demais na família. Aquilo entendido desde a perspectiva institucional como "violência intrafamiliar" abarcava rupturas nas trocas entre pessoas com diferenças de status e experiência em uma casa, descritas com uma linguagem sentimental e do dinheiro. Além disso, contemplava a transgressão da santidade da cucha, mostrando como a individualidade desses jovens estava vinculada a ela, estando sempre presentes noçóes como responsabilidade, cuidado e carinho.

Noçôes como direito e machismo, quando interpretadas pelos jovens, mostravam um universo de relaçôes e experiências que se distancia da imagem sobre os homens como população potencialmente ou de fato agressora. Chegar a ser um cucho não se esgota na ideia do indivíduo como cidadão, embora esta última contorne a individualidade, pois os jovens apelam a exercer seus direitos dentro de um contexto social de precariedade financeira quase permanente. 
Esses encontros reflexivos têm um limite no tipo de informação que circula e nas categorias que são ativadas, por isso também não é possível afirmar que o "modelo hegemônico" contempla o par cucho/violador ou o par cucho/homem com autoridade pública (policial, traficante, miliciano...). É tentador pensar que esses jovens váo ocupar o lugar de cuchos ou de detentores de um poder, sempre arbitrário, desconsiderando outras categorias de homens que não surgiram nos encontros e afirmando, de maneira implícita, que a violência faz parte da cultura local. Isto tira a capacidade de agência do indivíduo e inscreve "a violência" na ontologia, condenando esses jovens à repetição trágica do mito. Esta forma de considerar a aquisição da masculinidade também isola o meio social onde eles vivem, como se ele não estivesse conectado com o resto da cidade e outros modelos de ser homem, como o do facilitador.

Por outro lado, quero evitar a pergunta sobre o que estaria pensando ou sentindo o abusador, seus motivos para bater em alguém ou o que o teria legitimado a estuprar uma mulher. Embora sejam todas perguntas válidas para uma reflexão sobre o exercício da cidadania, essa forma de abordar o "ato violento" remete à individualização, correndo os já sabidos riscos de patologizar o comportamento, justificar as paixóes ou culturalizar a desigualdade de poder. A questão é ampla e complexa, pois a violência, por ser uma categoria moral, está inserida em redes de sentido que vão além da relação considerada pelas autoridades competentes em proteger ou julgar uma vítima (Simiáo, 2014). Cabe, nesse sentido, pensar em como o proceder individual do perpetrador de violência está em relação à trajetória de vida, à maneira como são criados os vínculos, às experimentadas relaçôes de poder e às configuradas formas de autoridade entre categorias de gênero e parentesco, onde homens e mulheres são partícipes. Deste modo, noçóes como impotência, medo, raiva, paixão, possessão do outro devem ser lidas em relação a como se criam redes de sentido e como se constitui o vínculo social.

Como trabalhar a nossa indignação em relação a certos objetos de reflexão? É possível ou mesmo desejável ignorar os nossos limites morais para analisar aquilo que chamamos de violência? Quando reconhecemos nosso limite moral, como o relacionamos com os imperativos morais desses outros com quem entramos em interlocução? Considero que um passo inicial está na compreensão da posição desses outros, em que a análise da reciprocidade complementa e nos ajuda a entender processos de subjetivação e conformação da noção de si (Moore, 2007). Compreender náo significa acreditar, pois isso seria cair no jogo de verdade e falsidade caracterizado por Foucault $(1993,1999)$ como próprio dos dispositivos de saber e poder que permitem classificar alguém como anormal. Compreender, 
neste caso, seria problematizar, também em um sentido foucaultiano, o fato de certo comportamento ou posição no discurso virar objeto de reflexão moral, científica e política em uma rede de relaçóes de poder que outorgam legitimidade às ações de reconhecimento, intervenção, punição e mudança desse objeto.

\section{Uma reapropriação do machismo}

Para finalizar este artigo, faço referência a um efeito inesperado das políticas de gênero contemporâneas, a apropriação das categorias classificatórias da perspectiva de gênero por um grupo de homens para justificar sua existência social. O Movimiento Machista Casanareño reivindica valores da cultura llanera sem apelar à etnicidade, em um intento de estabelecer relaçóes com o Estado, em prol do reconhecimento da sua identidade cidadá como machistas. De uma categoria de acusaçáo, machismo aqui passa a uma que define tanto a individualidade desses homens, redescrevendo o estigma como orgulho, quanto um modelo de ser homem que condensa valores sociais a ser recuperados para outorgar sentido a um proceder recentemente contestado à luz de argumentos legais e políticos de proteção à categoria mulher.

Este movimento surgiu no Departamento de Casanare, na planície da Orinoquia, região submetida durante a colônia espanhola ao controle de missóes para converter indígenas e reduzi-los a povoados. Naquela época, conformaramse grandes fazendas pecuárias pertencentes à elite política de Bogotá. No século XX, por causa dos acontecimentos de La Violencia, Casanare recebeu camponeses perseguidos pelos governos conservadores, conformando uma frente de colonização agrícola e pecuarista. Recebeu também as primeiras guerrilhas liberais de autodefesa campesina. Pela ineficácia do Estado central em proteger as propriedades dos fazendeiros, a conformaçáo de grupos paramilitares desde a década de 1980 ajudou a configurar a estrutura de possessão da terra, o conflito armado e o controle policial na regiáo. Atualmente, Casanare é uma das regióes com maior desenvolvimento do país, cuja economia depende do petróleo, da criação extensiva de gado e da agroindústria de palma africana para a produção de biodiesel. Ao mesmo tempo, é uma das regiôes mais "conservadoras" desde o ponto de vista da vanguarda progressista das grandes cidades colombianas.

O Movimiento Machista Casanareño foi fundado em 2002 por Edilberto Barreto, um homem de pouco mais de 60 anos, separado, proprietário de gado e responsável pela educação de "aproximadamente quatorze filhos". Ele foi demandado várias vezes por suas ex-companheiras para obrigá-lo a pagar a pensão alimentícia, tendo que responder por seus amoríos extraconjugais. "Ser macho neste país é coisa de macho [...]. É o preço por ser o garanhão do Llano 
[...]. Ainda não inventaram uma camisinha XL para mim”, comentava ele em uma entrevista concedida em 2011 ao site KienyKe, que causou a maior polêmica na Colômbia. Segundo um documentário que circulou na internet e na televisão nacional, Beto, como era chamado pelos amigos, queria recuperar as "antigas práticas machistas" do homem llanero que valorizavam o "gostar das mulheres" e "ser livre", requisitos para ingressar no movimento, além de já ter brigado com a sogra... Ele se reunia toda sexta-feira com vinte amigos em um bar na cidade de Yopal, longe das esposas e sogras, e no meio de bebidas e músicas populares, para discutir qual seria o melhor tratamento para as mulheres.

A intenção de Beto parece piada, mas ele e seus amigos justificavam o conflito por serem estigmatizados como sujeitos com processos legais, terem que responder por famílias numerosas, não terem meios de subsistência e não serem sujeitos de proteção estatal. Eles se diziam indignados porque, diante de um mercado de trabalho limitado, onde as práticas pecuárias estavam sendo absorvidas por grandes fazendeiros, só as mulheres eram consideradas população vulnerável, merecedora de programas de proteção e geração de renda. $\mathrm{Na}$ percepçáo de um dos amigos de Beto, há um conflito latente entre feminismo e machismo, colocando ambos os ideários como equivalentes e opostos na definição das relaçóes entre os sexos. Há antagonismo entre o reconhecimento da mulher como sujeito de direito para o Estado e a percepção do homem despossuído de autoridade dentro da família. Para eles, isto cria uma concorrência desnecessária entre os sexos para saber quem tem razão e quem manda na família. Esta posição, segundo algumas autoras, ${ }^{3}$ não é válida, porque o feminismo agencia um movimento de liberação e reconhecimento da dignidade e igualdade da mulher enquanto o machismo seria uma estrutura de relaçóes de opressão e subordinação.

Beto e seus amigos associam a hombría - o valor de ser forte, masculino, protetor, cavalheiro, entre outros atributos esperados pelas mulheres - ao machismo, categoria que melhor denota a autoridade masculina no lar e no espaço público. Hombría e machismo são características da cultura llanera, denominação folclórica de usos e costumes da regiáo da Orinoquia dentro do ideário nacional durante a segunda metade do século XX, que faz referência à mobilidade do homem llanero, amante da liberdade, trabalhador e empreendedor. Estas características compóem a "bravura da raça llanera", necessária para enfrentar os indígenas nativos e expandir a fronteira de produção. Para Beto, esta configuração cultural agora está oposta às novas leis vindas de Bogotá, que desqualificam o homem para dar razão às mulheres. Beto e seus amigos mostram um uso estratégico da retórica multiculturalista e das políticas da diferença, naturalizando a tradição para dar 
sentido à doxa segundo a qual há complementariedade entre os sexos: o homem dá proteção e meios físicos de subsistência através do trabalho árduo, e a mulher outorga "cuidado, carinho e beleza".

Esta relação entre caráter, raça e cultura não é absoluta para os homens do movimento. Existem matizes e discrepâncias. Um dos filhos de Beto, quando interrogado por um jornalista para compreender se as ideias do seu pai eram "novas" ou se estavam na cultura llanera, respondeu que efetivamente era algo que sempre esteve ali, que estava perdido, mas que agora eles estavam resgatando. Um amigo de Beto não negava a possibilidade de os homens fazerem os trabalhos do lar, como lavar roupas ou limpar o cháo. Contudo, náo considerava apropriada a disputa de poder no lar, pois o homem era a autoridade da família. A esse respeito, Beto mencionava que deixava sua esposa exercer o direito de pensar, mas não de opinar. Também descrevia a autoridade em termos de controle da mulher, fidelidade, exclusividade sexual e débito conjugal, importantes para a manutenção da relação. A desobediência delas legitimaria o castigo, equiparando o corpo da mulher ao do gado que deve ser tangido.

As mulheres entrevistadas compartilham e rejeitam atributos sobre o machismo. Uma jovem expressava sua ira porque Beto e seus seguidores consideravam as mulheres como animais. A indignação não era relativa à igualdade entre homens e mulheres; ela os lembrava de que eles foram todos paridos por uma mulher, ressaltando a sacralidade da pessoa da mãe. Outra mulher, um pouco mais velha, lamentava a possibilidade de o movimento ganhar as eleiçóes ao Senado e culpava a ignorância das mulheres, pois eram elas mesmas que patrocinavam práticas retrógradas como o machismo. Sobre este ponto, Beto mencionou que o movimento apoiava um candidato do partido liberal, mas que, infelizmente, eles não tiveram votos suficientes para chegar ao Congresso, ficando sem representação parlamentar.

Uma última entrevistada, na época namorada de Beto, valorizava o tratamento detallista do homem llanero. Ser detallista referia-se à qualidade que têm os homens de saber aquilo de que as mulheres precisam e providenciá-lo no momento adequado, garantindo assim bem-estar, felicidade e satisfação. Os "detalhes" na vida diária dáo conta do reconhecimento e apreço sentimental dos homens em relação a suas companheiras, que se expressa pela materialidade dos presentes, carregados de significado romântico. Para a namorada de Beto, quanto mais custoso o presente, mais consideração e amor carrega a relação. Um homem detallista é aquele que sabe conquistar a mulher, sendo cavalheiro, considerando a namorada ou esposa como uma reina. Agora, uma mulher detallista deve saber mimar seu marido, conhece os gostos dos seus familiares e se especializa em cuidar dos filhos. Ser detallista é ter 
a capacidade de atentar para todos os aspectos que fazem da vida verdadeiramente feliz e encantadora em todo momento. Para ela, não valorizar os detalles justifica as agressóes, pois implica o desconhecimento dos papéis de homens e mulheres, fazendo com que elas não sejam parceiras fiéis ou mães consagradas.

Fechando este episódio de "retrocesso" no avanço dos direitos das mulheres na Colômbia, em agosto de 2012 o deputado do partido socialista de Bogotá Iván Cepeda instaurou uma demanda contra Beto, segundo disposiçóes da Lei 1.257, de 2008, sobre violência contra a mulher. O deputado argumentou, no jornal de circulação nacional ElEspectador, que as declaraçôes "terríveis" de Beto não podiam ser ignoradas, pois justificavam mais crimes contra as mulheres: "este é um ato que constitui um gravíssimo atentado contra a dignidade das mulheres, que devem proteger-se a partir de todas as instâncias da sociedade”. No jornal, uma foto de um homem com a intenção de agredir uma mulher está acompanhada do texto "a violência contra as mulheres é um dos 'inimigos' do país" (El Espectador, 17 de agosto de 2012). Beto foi a prova fidedigna da existência da cultura patriarcal para muitas feministas e justificou a intervenção penal e a mobilização de acadêmicos, organizaçóes de mulheres e juristas em nome da igualdade e do direito a uma vida livre de violências. $\mathrm{Na}$ atualidade ainda existe uma página no Facebook com seguidores que respaldam as ideias de Beto.

Esses movimentos "neoconservadores" ou "masculinistas" têm sido denunciados por analistas do gênero e das masculinidades, que expressam seu desconcerto pela equiparação com o feminismo e pelo fato de não compartilharem os "benefícios" que trazem aos homens uma postura igualitária, como a possibilidade de expressar emoçóes, o fortalecimento do vínculo paterno e o compartilhamento da carga de manutenção do lar. Desde esta perspectiva civilizatória, justifica-se o fortalecimento e a sofisticação das políticas de prevenção e punição, através da análise acadêmica deste tipo de fenômeno - apresenta-se um presente problemático, produto de um passado tirano do qual o indivíduo deve se libertar (Mahmood, 2006) para se emancipar e se pensar como sujeito digno, agindo segundo a filosofia dos direitos humanos.

Esta concepçáo do tempo contrasta com a idealizaçáo do passado expressa por Beto e alguns homens de Bogotá nas rodas de conversa, cuja doxa trazia tranquilidade e outorgava sentido e orientação ao proceder no presente. Com a problematização do presente no encontro entre projeto igualitário e posiçôes de pessoas nas relaçóes de reciprocidade, instaurava-se um sentido de incerteza na definição de si para pensar futuras relaçóes — um sentimento de não-lugar, de desconhecimento do que sempre foram estes homens. Tanto para gestores da perspectiva de gênero quanto para homens adultos alvo das pesquisas e dos 
projetos de intervenção, o futuro é incerto. Para os primeiros, o controle e a previsibilidade do conhecimento científico e o absolutismo da filosofia liberal trazem certo sentido de controle do que os outros farão no futuro. Para os segundos, uma redefinição ética, uma sujeição ou talvez uma "resistência" são as opçóes para continuar a se posicionar diante da ideia de igualdade. Já para os jovens da periferia de Bogotá, o futuro parece mais um devir diante de múltiplas opçôes, possíveis só nas relações e sentidos que eles constroem em um ambiente social que os coloca em posiçóes limitadas. Chegar a ser não é uma escolha tão livre para eles.

Considero interessante como Beto, de maneira similar a outros movimentos políticos de evangélicos, apropria-se de categorias com as quais um discurso com legitimidade e poder de algum setor social (estatal, legal, acadêmico...) classifica certas pessoas ou população, que por sua vez se apropriam da categoria e a reelaboram, incorporando-a na sua identidade para se posicionar como sujeitos em condições de interlocução dialógica — neste caso, diante do Estado de Direito. Pensar e agir a partir do machismo permitiu ao movimento um tipo de ação social dentro dos parâmetros da política de gestão na democracia participativa, para legitimar atributos tidos por culturais como parte de seu reconhecimento como cidadãos.

$\mathrm{Na}$ Colômbia, processos de participação cidadã com base em atributos culturais foram pensados como re-etnização. A localização da cultura em uma alteridade extrema, a indígena, a afro-colombiana ou a camponesa, permitiu à antropologia considerar, estudar e apoiar este tipo de manifestação da "cultura local" como parte da pluralidade da nação colombiana. Porém, considero que a emergência do Movimiento Machista Casanareño, que se contrapóe à ideia de igualdade apelando a um certo multiculturalismo, é difícil de ser analisada sem barbarizar o outro, objeto da pesquisa. Isto mostra a perspectiva moral da análise, o engajamento do pesquisador com projetos de reivindicação, visibilidade ou mesmo tutela de minorias sociais e a capacidade ou não de colocar esses outros como interlocutores intelectuais, que dizer, como sujeitos.

O uso da categoria cultura pelos machos de Casanare não é um problema, no sentido que a civilisation conceberia à Kultur (Sahlins, 1997), mas um recurso que justifica formas de ser altamente questionadas desde os agentes das políticas de gênero. Como já argumentei quando me referi à relação entre cultura e gênero (Martínez, 2016), Kultur tem sido fundamental para as reivindicaçóes étnicas de povos indígenas, muitas vezes em confrontação à universalidade da retórica dos direitos humanos, como nos casos de mutilação feminina na África ou acordos matrimoniais na Índia. Ao mesmo tempo, tem servido para os agentes 
da civilisation designarem o outro, objeto da empresa colonial. Kultur tem sido utilizada pelos antropólogos para refletir acerca das relaçóes de comunidades étnicas com sociedades nacionais. No caso dos jovens, há um processo pelo qual indivíduos sem identificação étnica são culturalizados, com o conteúdo de Kultur, através da tentativa civilizatória de compreender e eliminar a violência dos homens. No caso do movimento machista, sujeitos que se consideram parte da civilisation "revivem" atributos da Kultur para se manter como dignos perante o Estado de Direito.

Como mencionam vários autores para o sudeste asiático, o revivalismo como tradicionalismo faz parte de um processo local de reinvenção da tradição, partindo de categorias coloniais assinaladas aos indígenas pelos estrangeiros, e remete ao complexo de direitos e obrigaçôes que vincula história, território e lei, legitimando o domínio de um grupo sobre a terra (Henley \& Davison, 2007). Também legitima, de maneira mais abstrata, um ideal de sociedade em termos de autenticidade, comunidade, harmonia, ordem e justiça. O uso contemporâneo do adat, kastom ou kultura, para tomar como exemplo o Timor Leste, implica uma "manipulação da tradição" pelos interesses dos atores envolvidos, que invocam um ideal social com fins políticos na sua relação com agências modernizadoras, como organismos das Naçóes Unidas, ao mesmo tempo que, nos discursos governamentais, vinculam valores dos direitos humanos ao conhecimento do local (Silva \& Simião, 2012).

\section{Consideraçóes finais}

Neste artigo, propus resgatar a análise da reciprocidade e do lugar da pessoa nas relaçóes sociais para compreender fenômenos políticos e relaçôes consideradas violentas desde uma perspectiva liberal, igualitária e individualista. Considero importante lembrar que o indivíduo ou a pessoa náo tem existência social em si; são construtos analíticos que nos ajudam a nos aproximar de como nossos interlocutores no campo posicionam-se e constroem suas relaçóes sociais. Noçóes como indivíduo, pessoa e sujeito ajudam a compreender processos de identificação e noçôes de poder, como possessão do indivíduo e como construído na relação, criando formas de autoridade. Deste modo, o modelo de masculinidade pode ser compreendido como processos dinâmicos na relação entre modelos, que não são tâo rígidos ou verticais, e o discurso da igualdade e cidadania, onde não necessariamente temos um sujeito político, mas sim posiçóes que valorizam de maneiras circunstanciais tanto a igualdade quanto a diferença. 
Argumentei que o uso das categorias de cultura, gênero e igualdade conjuga três tempos e constrói a masculinidade como uma problemática social a analisar e intervir, em oposição moral à ideia de cidadáo, à simetria e à relação indivíduosociedade. Essa configuração constrói um outro com excesso de tradição, o qual justifica exercícios de governo que criam discursos e práticas localizadas, mostrando o encontro entre moralidades em relaçáo antagônica na definiçáo do proceder ético. A cultura é uma categoria poderosa capaz de moralizar o passado segundo o agente. Seja como idealização harmônica, seja como tirania da qual o indivíduo deve se emancipar, a cultura fundamenta posiçôes políticas tendo como referente o reconhecimento e a participação cidadã. A posição do pesquisador em relaçáo à cultura permite valorizar ou estigmatizar tanto o passado quanto os nossos interlocutores. Esta é uma consideração política importante, pois evidencia os irredutíveis morais do analista e posiciona de maneira mais clara os alcances da pesquisa.

Considero importante seguir as pistas do uso da categoria de gênero no contexto político contemporâneo, marcado pela polarização de posiçôes a favor e contra uma cidadania igualitária, universal e respeitosa das diferenças. Como mostrei, categorias como cultura e gênero não são propriedade exclusiva de acadêmicos; elas ganham vida com as apropriaçôes de indivíduos e coletivos na arena política e intelectual. Formas de classificaçáo de atitudes e comportamentos em circunstâncias particulares viram elementos identitários, muitas vezes contradizendo o sentido original intencionado por autores, pesquisadores ou ativistas (Simião, 2005). O conhecimento científico não é neutro, um postulado de ampla aceitaçáo no meio acadêmico, pois tem um lugar de enunciação e de poder. Os homens que são objeto de reflexão da categoria de masculinidade também estão nessa relação, e a posição deles não pode ser desconsiderada nem política nem academicamente - não para aceitar ou negar a posição deles como sujeitos necessariamente, mas para compreender fenômenos sociais dos quais os indivíduos são partícipes, mas que estão além do seu poder. Em outras palavras, para colocar o sujeito na tensa relação entre indivíduo e pessoa, entre discursos e relaçóes de reciprocidade que configuram o elo social.

Recebido em: 17/08/2014

Aprovado em: 03/02/2016 
Marco Julián Martínez Moreno é doutorando do Programa de PósGraduação em Antropologia Social da Universidade de Brasília e bolsista do CNPq. Interessa-se pela antropologia das moralidades, do gênero e do individualismo. É pesquisador do Laboratório de Estudos da Cidadania, Administração de Conflitos e Justiça (Caju) e do Instituto de Estudos Comparados e Administração Institucional de Conflitos (InEAC). Faz parte do grupo Conflito Social e Violência do Centro de Estudos Sociais da Universidade Nacional de Colômbia. É autor e coordenador de publicaçóes acadêmicas com a Universidade Nacional de Colômbia e editor convidado da Revista Universitas Humanistica, da Pontificia Universidad Javeriana. E-mail: akkmjm@gmail.com

\section{Notas}

1. Em uma comunicação pessoal em 2012, Daniel Simião comentava como em Timor Leste os criminosos que iam para a prisão entendiam esta pena como um momento de descanso, de lazer talvez. A ausência de uma compreensão da "liberdade", como entendida pelos ocidentais, fazia que o encarceramento não surtisse o mesmo efeito coercitivo para os timorenses.

2. Participaram do processo de intervenção social 436 homens em 20 grupos, cada um com oito encontros de duas ou três horas cada. Eles eram adolescentes, adultos e idosos vinculados a programas sociais da prefeitura de Bogotá, moradores de bairros pobres, onde era focalizado o Programa de Intervenção Integral às Violências Intrafamiliar e Sexual do Departamento Administrativo de Bem-Estar Social.

3. Ver entrevista do Centro Latino-Americano em Sexualidade e Direitos Humanos com Mara Viveros, Masculinidades e violência, consultada em fevereiro de 2014 em http://www.clam.org.br/entrevistas/conteudo.asp?cod=9819. 


\section{Referências}

BEIRAS, Adriano. 2012. La (de)construcción de subjetividades en un grupo terapéutico para hombres autores de violencia en sus relaciones afectivas. Tese de doutorado em psicologia social, Universitat Autònoma de Barcelona.

CONNEL, Raewyn. 2005. Masculinities. Berkeley e Los Angeles: University of California Press. Publicado originalmente em 1995.

CONNELL, Raewyn W. \& MESSERSCHMIDT, James. 2005. "Hegemonic masculinity: rethinking the concept". Gender and Society, 19(6):829-859.

DUMONT, Louis. 1970. Homo hierarchicus: the caste system and its implications. Chicago: The University of Chicago Press. Publicado originalmente em 1966.

FOUCAULT, Michel. 1993. La microfisica del poder. Madrid: La Piqueta. . 1999. "La gubernamentalidad". In: Estética, ética y hermenéutica. Barcelona: Paidós.

GÓMEZ, Freddy \& GARCÍA, Carlos Iván. 2006. "Masculinity and violence in Colombia: deconstructing the conventional way of becoming a man". In: Ian Bannon \& Maria Correia (eds.). The other half of gender: men's issues in development. Washington: The World Bank, p. 93-110.

GUTMANN, Matthew. 1997. "Trafficking in men: the anthropology of masculinity". Annual Review of Anthropology, 26:385-409.

GUZMÁN, Germán. 1968. La violencia en Colombia, parte descriptiva. Cali: Progreso.

HENLEY, David \& DAVIDSON, Jamie. 2007. "Introduction: radical conservatism — the protean politics of adat". In: Jamie Davison \& David Henley (Eds.). The revival of tradition in Indonesian politics: the deployment of adat from colonialism to indigenism. London, New York: Routledge. pp. 1-49.

JIMENO, Myriam; GÓNGORA, Andrés; MARTÍNEZ Marco Julián; \& SUÁREZ, Carlos José. 2007. Manes, mansitos y manazos: una metodología de trabajo sobre violencia intrafamiliar y sexual. Bogotá: Universidad Nacional de Colombia, Departamento Administrativo de Bienestar Social.

MAHMOOD, Saba. 2006. "Teoria feminista, agência e sujeito liberatório: algumas reflexôes sobre o revivalismo islâmico no Egipto”. Etnográfica, 10(1):121-158.

MALINOWSKI, Bronislaw. 1973. Los argonautas del Pacifico occidental: comercio y aventura entre los indígenas de la Nueva Guinea melanésica. Barcelona: Península. Publicado originalmente em 1922. 
MARTÍNEZ, Marco Julián. 2012a. "Entre a violência e a paz pelo caminho da cultura: produçáo de cidadáos na democracia familiar". In: Andréa Lobo (org.). Entre fluxos. Brasília: Editora Universidade de Brasília. pp. 165-193.

2012b. "Un nuevo primitivo: cultura, género e igualdad en la transformación hacia una sociedad democrática”. Revista de Antropologia, 55(2):147-180.

.2013. Da "cultura de la violencia" à "democracia familiar": masculinidade, cultura e conformação da alteridade em uma política pública de Bogotá, Colômbia. Dissertaçáo de mestrado em antropologia social, Universidade de Brasília.

. 2014. "Modernizando al hombre como sujeto de derecho, cultural y con género: un momento etnográfico en el campo de las masculinidades". IM-Pertinente, 2(2):39-61.

2016. Ser ñero, muchacho e novo homem: cultura, reciprocidade e gênero na relação entre violência e masculinidade. Inédito.

MAUSS, Marcel. 2011. "Ensaio sobre a dádiva: forma e razão da troca nas sociedades arcaicas". In: Sociologia e antropologia. São Paulo: Cosac Naify. pp. 183-313. Publicado originalmente em 1925.

MOORE, Henrietta L. 1994. A passion for difference: essays in anthropology and gender. Bloomington and Indianapolis: Indiana University Press.

. 2007. The subject of anthropology: gender, symbolism and psychoanalysis. Cambridge and Malden: Polity Press.

NASCIMENTO, Marcos. 2001. Desaprendendo o silêncio: uma experiência com grupos de homens autores de violência contra a mulher. Dissertação de mestrado em saúde coletiva, Universidade do Estado do Rio de Janeiro.

SAHLINS, Marshall. 1997. "O 'pessimismo sentimental' e a experiência etnográfica: por que a cultura não é um 'objeto’ em via de extinção (parte I)”. Mana, 3(1):41-73.

SILVA, Kelly; SIMIÃO, Daniel. 2012. "Coping with 'traditions': the analysis of EastTimorese nation building from the perspective of a certain anthropology made in Brazil”. Vibrant, 9(1):360-381.

SIMIÁO, Daniel. 2005. As donas da palavra: gênero, justiça e a invenção da violência doméstica em Timor Leste. Tese de doutorado em antropologia, Universidade de Brasília.

2014. "Sensibilidades jurídicas e respeito às diferenças: cultura, controle e negociação de sentidos em práticas judiciais no Brasil e em Timor-Leste". Anuário Antropológico, 39(2):237-260. 
STOLCKE, Verena. 2001. "Gloria o maldición del individualismo moderno". Revista de Antropologia, 44(2):7-37.

STRATHERN, Marylin. 2006. O gênero da dádiva: problemas com as mulheres $e$ problemas com a sociedade na Melanésia. Campinas: Editora Unicamp. Publicado originalmente em 1988.

VALE DE ALMEIDA, Miguel. 1996. "Gênero, masculinidade e poder: revendo um caso do sul de Portugal”. Anuário Antropológico, 95:161-190.

VIVEROS, Mara. 2002. De quebradores y cumplidores: sobre hombres, masculinidades y relaciones de género en Colombia. Bogotá: Universidad Nacional de Colombia, Fundación Ford y Profamilia.

2003. "Perspectivas latinoamericanas actuales sobre la masculinidad". In: Patricia Tovar (org.). Familia, género y antropología: desafíos y transformaciones. Bogotá: Instituto Colombiano de Antropología e Historia. pp. 82-129. 


\section{Resumo}

Neste artigo, proponho complementar a análise individualista do campo das masculinidades com as noçôes de pessoa e reciprocidade para compreender melhor relaçóes tidas por violentas e sujeitos que, nesse campo, são constituídos em oposição moral à noção de cidadão. Com isto, apelo à revisão de supostos epistemológicos do pesquisador no seu trabalho de classificar e analisar identidades, práticas e relações desde uma perspectiva de gênero, que está em relação estreita com a noção de cultura. Argumento que as categorias de gênero e cultura conjugam três tempos que constroem a masculinidade como uma problemática social a intervir em função de um projeto igualitário. Por último, mostro como alguns homens na Colômbia apropriam-se de categorias próprias de um repertório individualista, transformando a acusação de machistas em identidade para justificar sua existência social como sujeitos de direito.

Palavras-chave: individualismo, reciprocidade, gênero, cultura, sujeito
In this article I propose to complement the individualistic perspective on the field of masculinities with the categories of 'person' and 'reciprocity'. Both of them help to understand the violent relationships and the subjects that are conceived in moral opposition to the idea of citizenship. With that in mind, I suggest researchers revise the epistemological background of gender and culture when classifying and analyzing identities, practices, and relationships during fieldwork. I argue that the categories of gender and culture configure an evolutionary chronology where masculinity is conceived as a social problem that requires intervention so that the egalitarian utopia is achieved. Lastly, this article describes how some Colombian men appropriate individualistic categories, transforming the accusation of machistas into a social identity.

Keywords: individualism, reciprocity, gender, culture, subject. 